\title{
Restoran İşletmelerinin Menülerindeki Yöresel Yemekleri İnceleyen Yerli Yazın Üzerine Bir Meta Sentez Çalışmasıı ${ }^{1}$ (Araştırma Makalesi)
}

\section{A Meta Synthesis Study on the Local Literature Examining Local Dishes in Restaurant Menus}

Doi: 10.29023/alanyaakademik.851849

\section{Oğuz NEBİOĞLU}

Dr. Öğr. Üyesi., Alanya Alaaddin Keykubat Üniversitesi, Turizm Fakültesi, Turizm Rehberliği Bölümü

oguz.nebioglu@alanya.edu.tr

Orcid No: 0000-0002-3436-7754

Bu makaleye atıfta bulunmak için: Nebioğlu, O., (2021). "Restoran İşletmelerinin Menülerindeki Yöresel Yemekleri İnceleyen Yerli Yazın Üzerine Bir Meta Sentez Çalışması”. Alanya Akademik Bakış, 5(2), Sayfa No.1031-1047.

\begin{abstract}
Anahtar kelimeler:
Menü,

Meta Sentez,

Restoranlar,

Yöresel Yemekler

Makale Geliş Tarihi:

02.01.2021

Kabul Tarihi:

17.05.2021

$\overline{B u \text { çalışma, Türkiye'de yöresel yemeklerin restoranlarda sunumunu şehirler }}$ bazında ele alan araştırmaların bulgularını yeniden yorumlayarak bütüncül çıkarımlarda bulunmayı amaçlamaktadır. Çalışma verileri, Türkiye'nin çeşitli şehirlerindeki restoranlarda yöresel yemekleri inceleyen on dört araştırmadan toplanmıştır. Bu araştırmalar meta sentez yöntemi ile ele alınmış ve veriler içerik analizine tabi tutulmuştur. Bulgulara göre yöresel mutfak ve turizm ilişsisi sürdürülebilirlik, pazarlama aracı olma ve deneyim aracı olma şeklinde üç boyutta ortaya çımaktadır. Yöresel yemeklere restoranlarında çoğunlukla yer veren şehirler Gaziantep, Mersin, Adana ve Bolu'dur. Araştırma kapsaminda incelenen diğer şehir restoranlarında yöresel yemeklere çok fazla yer verilmediği görülmektedir. Yöresel yemeklerin restoranlarda sunulmasında hem üretim hem de tüketime bağll faktörlerin etkili olduğu anlaşılmaktadır. Araştırmalar çoğunlukla yöresel yemeklerin yaşatılması ve yaygınlaştırılması üzerine öneriler sunmaktadır. Son olarak tüm bulgular üzerinden bir tartışma yürütülmüş, teorik ve pratik çıkarımlar sunulmuştur.
\end{abstract}

\section{ÖZET}

\section{ABSTRACT}

Keywords:

This study aims to make holistic inferences by reinterpreting the findings of the studies that deal with the presentation of local foods in restaurants in Turkey on the basis of cities. The data used in the study, which examined

Menu,

Meta Synthesis,

Restaurants,

Local Dishes Turkey's local dishes at restaurants in various cities, were obtained from fourteen research. These studies were handled with meta synthesis method and the data were subjected to content analysis. According to the findings, the relationship between local cuisine and tourism appears in three

\footnotetext{
${ }^{1} \mathrm{Bu}$ çalışma, 06-07.12.2020 tarihinde online olarak düzenlenen 9. Ulusal Kırsal Turizm Kongresi'nde sunulan "Türkiye'deki Restoran Menülerinde Yöresel Yemekleri İnceleyen Araştırmalar Üzerine Bir Meta Sentez Çalışması”" başlıklı özet bildirinin genişletilmiş halidir.
} 


\begin{abstract}
dimensions as sustainability, being a marketing tool, and an experience tool. The cities that mostly presents local dishes in their restaurants are Gaziantep, Mersin, Adana and Bolu. It is seen that local dishes are not presented much in other city restaurants examined within the scope of the research. It is understood that factors related to both production and consumption are effective in the presentation of local dishes in restaurants. Researches mostly offer suggestions on the rediscovering and dissemination of local dishes. Finally, a discussion was made on all the findings, and theoretical and practical inferences were presented.
\end{abstract}

\title{
1. GİRIŞ
}

Turizm etkinlikleri çeşitli amaçlarla gerçekleşebilir. Bu etkinlikler bazen farklı bir kültürü tanıma, dinlenme, eğlenme, din gibi çok yaygın nedenlerle; bazen de spor, sağlık, kongre gibi daha spesifik motivasyonlarla yapılır. Hangi amaçlarla olursa olsun yemek, turizm etkinliklerinin tümü için vazgeçilmezdir (Nebioğlu 2018). İnsan yaşamı için hayati önem taşıyan bu olgu, günümüzde gastronomi kavramı altında zenginleşen bir yapı kazanmıştır. İnsanların fizyolojik ihtiyaçlarını karşılamanın dışında ziyaret edilen bölgeyi daha iyi deneyimleme imkânı sunan bir işleve bürünmüştür (Everett 2012). Böylelikle geçmişte seyahatlerin görünmez bir parçasıyken, günümüzde gastronomi çatısı altında yeni ve ilgi çekici bir alternatif turizm kaynağı olarak görülmeye başlamıştır.

Gastronomi turizmi bir bölge kültürünün o bölgenin sahip olduğu gastronomik unsurlarla deneyimlenmesi biçiminde tanımlanabilir (Kivela ve Crotts 2005). Birden fazla duyuya hitap etmesinden dolayı yemek, turizm deneyimini zenginleştirmekte ve turistlere unutulmaz deneyimler sunmaktadır (Everett 2012). Bu deneyimler ise bölgenin sahip olduğu gastronomik unsurların farklı biçimlerde deneyimlenmesi yoluyla gerçekleşmektedir. Turistlerin gastronomik deneyimlerinin yöresel mutfağa olan ilgiyi arttıracağı, sürdürülebilir mutfak mirasına ve yerel ekonomiye katkı sunacağı ifade edilmektedir (DuRand vd. 2003; Haven-Tang ve Jones; 2005).

Burada iki konu dikkat çekmektedir. Bunlardan ilki gastronomik unsurların neler olduğudur. Turizm bağlamında ele alınan gastronomik unsurlar temel olarak bir bölgenin çevresel ve kültürel özellikleri ile eşsiz bir rol kazanmış yöresel ürünlerini ifade etmektedir (Harrington 2005). İkinci konu ise bu gastronomik ürünlerin nasıl deneyimlendiğidir. Festivaller, kongreler, pazarlar, restoranlar gastronomik unsurların turistler tarafından başlıca deneyimlendiği yerler olarak tanımlanmaktadır (Smith ve Xiao 2008). Bu yerler arasında restoranlar yaygınlık, hizmet saatleri ve ürün çeşitliliği bakımından diğer deneyim alanlarından ayrılarak öne çıkmaktadır. Restoranlar hem turistik bir deneyim alanı olarak gündelik hayatta hem de akademik bir çalışma olarak turizm ve gastronomi bağlamında oldukça ilgi görmeye başlamıştır (Ak 2019).

Bu kapsamda ele alınan çalışmaların genel olarak turist perspektifini yansıttıkları söylenebilir. Turistlerin restoranlardaki yemek yeme nedenleri; restoran seçimlerindeki bilgi kaynakları; (Sparks vd. 2003; Batra 2008); restoran seçimlerinde dikkat ettikleri faktörler (Yüksel ve Yüksel 2002; Lilliwhite ve Simonsen 2014); restoranlarda sunulan ürünlere yönelik talepleri (Reynolds, 1993; Yüksel ve Yüksel, 2002; Sparks vd., 2003) ve restoranlardaki tutum ve davranışları (Bekar ve Kılıç, 2014; Birdir ve Akgöl, 2015) gibi konular buna örnek gösterilebilir. 
Konuya restoran işletmeciliği açısından yaklaşan çalışmalar turist perspektifinden yapılan çalışmalara nazaran yerelliğe daha açık şekilde vurgu yaparlar. Restoranların yerel yiyecek kullanmasının önemi, yerel yiyecek tedariki (Sims 2009; Curtis ve Cowee 2009; Dougherty ve Green 2011; Kyriakaki vd. 2013; Sharma vd. 2014; Kormann da Silva vd. 2015, Özdemir vd. 2015) ve yöresel yemeklerin restoranlarda ne dereceye kadar sunuldukları (Reynolds 1993; Kızılırmak vd. 2014; Yarış ve Cömert 2015) gibi konular işletmecilik bağlamında irdelenir.

$\mathrm{Bu}$ araştırmalar arasında son yıllarda yöresel yemeklerin restoranlarda sunumunu ele alan oldukça fazla çalışmaya rastlanır. Bu çalışmaların çoğunlukla bir şehirle sınırlandırılmış oldukları görülür. Söz konusu çalışmalar yöresel yemeklerin restoran menülerinde yer alma durumlarını ortaya koyarken; yöresel yemeklerin kullanımını arttırmak adına yapılması gerekenleri de tartışmaktadır. Diğer bir ifadeyle bu çalışmalar inceledikleri şehirlere dair oldukça değerli bilgiler sunmaktadır. Bu araştırma ise bölgesel bazda sunulan bu bulguları sentezlemeyi, böylece bu araştırmaların bulguları yardımıyla bütüncül çıkarımlar yapabilmeyi hedeflemiştir. Meta sentez yöntemi doğası gereği öncül nitel araştırma bulgularının daha kapsamlı ve anlaşılır bir vizyonunu ortaya koyduğu gerçeğine göre, bu araştırmanın amacına hizmet edeceği söylenebilir (Yahyapour, Shamizanjani ve Mosakhani 2015).

\section{TURIZM BAĞLAMINDA YÖRESEL ÜRÜNLER VE RESTORANLAR ÜZERINE YAPILAN ÇALIŞMALAR}

Dinamik yapısından dolayı gastronomide yöresel kavramını tanımlamak oldukça zordur (Nebioğlu 2020). Bu nedenle alanyazında yöreseli tanımlayan ve bunu yaparken de farklı konuları vurgulayan çalışmalara rastlanır (Hu vd. 2010). Bu çalışmalara göre yöresel ürünler ülke, bölge, mesafe ve kültür gibi farklı yönleriyle tanımlanabilir (Özdemir vd. 2015). Turist perspektifinden bakıldığında yöresel ürünler "bir bölgeyi ve kültürü simgeleyen veya turistlere otantik deneyimler yaşatan ürünler" olarak tanımlanabilir (Sims 2009). Arz perspektifinden ise belirli bir bölgede üretilen yiyecek ve içecekler veya yerel kimliğe sahip özel yiyecekler olarak tanımlanır (Nummedal \& Hall, 2008). Bu tanıma göre yöresel ürünler belirli bir coğrafya ile bağ kurmuş (Haven-Tang ve Jones 2008; Blakey 2011), kökeni, adı ve ünü belirli bir yöreye ait olan ürünler olarak tanımlanabilir (Kabasakal 2015). Her iki perspektifin ortak noktası ise yöreseli coğrafi, sosyokültürel ve ekonomik bağlarla ele almalarıdır.

Alanyazında yöresel ürünler üzerine yapılan çalışmaların iki farklı alanda yapıldıkları söylenebilir. Bunlardan ilki yerel yiyeceklerdir. Genellikle yerel tarım ürünlerini ele alan bu araştırmalar şeflerin restoranları için yerel ürün tercihleri konusuna odaklanmaktadır (Sims 2009; Curtis ve Cowee 2009; Dougherty ve Green 2011; Kyriakaki vd. 2013; Sharma vd. 2014; Kormann da Silva vd. 2015, Özdemir vd. 2015). Bu araştırmalar yerel ürünlerin taze, lezzetli, sağlıklı oldukları, yerel ekonomiye ve sürdürülebilir tarıma katkı yaptığını vurgular.

Yerel tarım ürünleri dışında kalan çalışmalar ise yöresel yemeklerin restoranlarda sunumu üzerinde durur. Bunu da turizm bağlamında ele alır. Sözgelimi Reynolds (1993) Bali'de faaliyet gösteren restoran menülerinde yöresel yemeklere yer verme durumunu incelemiştir. Araştırma çerçevesinde beş yıllık bir dönemde Bali'de faaliyet gösteren restoran menüleri taranmış ve yöresel yemeklerin restoran menülerinde gittikçe daha az yer aldığı sonucuna ulaşılmıştır. Avieli'nin (2013) çalışması ise Vietnam'ın Hoi Ann şehrinde turizmin etkisiyle yöresel yemeklerdeki gastronomik değişimleri irdeler. Yerelin turizm etkisiyle restoranlarda 
yaşadığı dönüşüm örneklendirilerek bu araştırmada anlatılır. Wang vd. (2014) tarafından Vietnam'da yapılan bir araştırma ise yöresel yemeklerin servis kalitesini belirlemek üzere gerçekleştirilmiştir. Araştırma bulguları yöresel yemeklerin sunumunda iletişim gibi eksikliklerin olduğunu göstermektedir. Botelho vd.'nin (2020) yapmış olduğu çalışmada ise Kuzeydoğu Brezilya restoranlarında sunulan yöresel yemekler ve bu yemeklerin sunulma nedenleri incelenmiştir. Yöresel yemeklerin müşteriler tarafından talep görmesi başlıca sunulma nedeni olarak görülmektedir.

Yukarıdaki araştırmalara göre yöresel ürünler (tarım ürünleri ve yöresel yemekler) gastronomi ve turizm ilişkisinde önemli bir paya sahiptir. Yerelin kazandırdığı eşsiz olma, kolay taklit edilememe, sürdürülebilir olma gibi özelliklerin tümü yöresel ürünler için geçerlidir ve yerelin turizmde etkin kullanımı özellikle gastronomik deneyimleri zenginleştireceği anlamına gelmektedir. Bu alanda yapılan pek çok çalışma yöresel ürünlerin turistik destinasyonlar için ihtiyaç duyulan gastronomik ürün niteliklerini karşıladıklarını ifade ederler (Sims 2009). Destinasyonda kullanılan yöresel gastronomik ürünler destinasyonun rakip destinasyonlar karşısında daha farklı, rekabetçi ve güçlü olmasına katkı sunarlar. Yöresel yemeklerin restoranlarda temsilinin turizm etkinlikleri için başat bir rol üstlendiklerini; yokluklarının ise tam tersine önemli bir başarısılık olarak addedildiğini vurgularlar. Bu ifadelerden yola çıkarak son yıllarda ülkemizde de turizm bağlamında yöresel yemekler ve restoranlar üzerine odaklanan alanyazının geliştiği görülmektedir.

\subsection{Türkiye'de Yöresel Yemeklerin Restoranlarda Sunumu Üzerine Yapılan Çalışmalar}

Türk mutfağı köklü bir tarihe sahip, pek çok çevresel ve kültürel etmenin etkisiyle gelişmiş oldukça zengin bir mutfaktır. Bu mutfak en genel haliyle iki boyutta incelenebilir. Klasik Türk mutfağı ve Türk halk mutfağı. Klasik Türk mutfağı Osmanlı Saray mutfağını tanımlar. Türk halk mutfağı ise bulunulan bölgenin coğrafyasının ve yerel kültürün etkisiyle şekillenen, taşra kaynaklı, bölgesel mutfakları ifade eder (Şavkay 2000). Dünyanın diğer bölgelerinde olduğu gibi coğrafi yapının etkisi, geçmiş yıllarda insanların bulundukları coğrafyada yetişen ürünlere dayalı bir mutfak kimliği geliştirdiklerini göstermektedir (Hall ve Mitchell 2002). Türk mutfağı da halk mutfağı özelinde benzer bir gelişim içinde olmuş ve Anadolu Coğrafyasının yedi farklı coğrafi bölgesinde farklı yöresel mutfak kimlikleri gelişmiştir (Gürsoy 2013).

$\mathrm{Bu}$ yöresel mutfaklar bölgelerin sosyokültürel zenginliklerinin bir göstergesi olurken; günümüzde gastronominin gelişimiyle doğru orantılı olarak turizmle ilişkilendirilmeye başlamıştır. $\mathrm{Bu}$ nedenle ulusal alanyazında yöresel yemeklerin restoranlarda sunumunu turizm bağlamında ele alan çalışmaların sayısı hızla artış göstermiştir. Bu araştırmalar turizm ve gastronomi ilişkisini yöresel yemekler üzerinden restoranlarla ilişkilendirerek kurmayı amaç edinmişlerdir.

Tablo 1. Türkiye'de Yöresel Yemeklerin Restoranlarda Sunulmasını İnceleyen Araștırmalar

\begin{tabular}{llllllc}
\hline $\begin{array}{l}\text { Araştırma } \\
\text { Kodu }\end{array}$ & $\begin{array}{l}\text { Araştırma } \\
\text { Türü }\end{array}$ & $\begin{array}{l}\text { Araştırma } \\
\text { Yöntemi }\end{array}$ & Şehir & Restoran Türü & $\begin{array}{l}\text { İncelenen } \\
\text { Restoran } \\
\text { Sayısı }\end{array}$ & $\begin{array}{l}\text { Yazar/lar ve } \\
\text { Yıl }\end{array}$ \\
\hline A1 & Makale & Nitel & $\begin{array}{l}\text { Trabzon } \\
\text { (Uzungöl) }\end{array}$ & $\begin{array}{l}\text { Bağımsız ve otel } \\
\text { restoranları }\end{array}$ & 13 & $\begin{array}{l}\text { Kızılırmak } \\
\text { vd. (2014) }\end{array}$ \\
A2 & Makale & Nitel & $\begin{array}{l}\text { Erzurum } \\
\text { (Palandöken) }\end{array}$ & Otel restoranları & 5 & $\begin{array}{l}\text { Mil ve Denk } \\
(2015)\end{array}$ \\
\hline
\end{tabular}




\begin{tabular}{|c|c|c|c|c|c|c|}
\hline $\mathbf{A 3}$ & Makale & Nitel & $\begin{array}{l}\text { Rize } \\
\text { (Çamlıhemşin) }\end{array}$ & $\begin{array}{l}\text { Bağımsız } \\
\text { restoranlar }\end{array}$ & 7 & $\begin{array}{l}\text { Çokişler ve } \\
\text { Türker (2015) }\end{array}$ \\
\hline A4 & Makale & Karma & Konya & $\begin{array}{l}\text { Bağımsız } \\
\text { restoranlar }\end{array}$ & 29 & $\begin{array}{l}\text { Büyükş̧alvarc } \\
1 \text { vd. (2016) }\end{array}$ \\
\hline A5 & Bildiri & Nitel & Gaziantep & $\begin{array}{l}\text { Bağımsız } \\
\text { restoranlar }\end{array}$ & 41 & $\begin{array}{l}\text { Giritlioğlu vd. } \\
\text { (2016) }\end{array}$ \\
\hline A6 & Bildiri & Nitel & $\begin{array}{l}\text { Sakarya } \\
\text { (Taraklı) }\end{array}$ & $\begin{array}{l}\text { Bağımsız ve otel } \\
\text { restoranları }\end{array}$ & 8 & $\begin{array}{l}\text { Akdemir ve } \\
\text { Selçuk (2017) }\end{array}$ \\
\hline A7 & Makale & Karma & Karaman & $\begin{array}{l}\text { Bağımsız } \\
\text { restoranlar }\end{array}$ & 32 & $\begin{array}{l}\text { Aylan vd. } \\
(2017)\end{array}$ \\
\hline A8 & Makale & Nitel & Eskişehir & $\begin{array}{l}\text { Bağımsız ve otel } \\
\text { restoranları }\end{array}$ & 53 & $\begin{array}{l}\text { Dündar } \\
\text { Arıkan (2017) }\end{array}$ \\
\hline A9 & Makale & Nitel & Kilis & $\begin{array}{l}\text { Bağımsız } \\
\text { restoranlar }\end{array}$ & 11 & $\begin{array}{l}\text { Özel vd. } \\
(2017)\end{array}$ \\
\hline A10 & Bildiri & Nitel & Adiyaman & Otel restoranları & 12 & $\begin{array}{l}\text { Yeşilyurt vd. } \\
\text { (2017) }\end{array}$ \\
\hline A11 & Makale & Nitel & Bolu (Mengen) & $\begin{array}{l}\text { Bağımsız } \\
\text { restoranlar }\end{array}$ & 8 & $\begin{array}{l}\text { Erdem vd. } \\
(2018)\end{array}$ \\
\hline A12 & Makale & Nitel & Sinop & $\begin{array}{l}\text { Bağımsız } \\
\text { restoranlar }\end{array}$ & 18 & $\begin{array}{l}\text { Kargiglioğlu } \\
\text { ve Ayyıldız } \\
(2018)\end{array}$ \\
\hline A13 & Makale & Nitel & Erzincan & $\begin{array}{l}\text { Bağımsız } \\
\text { restoranlar }\end{array}$ & 17 & $\begin{array}{l}\text { Şen } \\
\text { Silahşör } \\
(2018)\end{array}$ \\
\hline A14 & Makale & Karma & $\begin{array}{l}\text { Adana ve } \\
\text { Mersin }\end{array}$ & $\begin{array}{l}\text { Bağımsız } \\
\text { restoranlar }\end{array}$ & 212 & $\begin{array}{l}\text { Yildırım vd. } \\
(2018)\end{array}$ \\
\hline
\end{tabular}

Tablo 1 bu araştırmalar hakkında bilgiler sunmaktadır. Araştırmaya dahil edilen çalışmaların tümü "Yöresel yemeklerin restoranlarda sunulma düzeyini" incelemektedir. Bu ifadeden kasıt, yine tüm çalışmalarda yöresel yemeklerin restoran menülerinde yer alma durumu olarak belirtilmiştir. Aynı zamanda araştırmaya dahil edilen çalışmaların tamamında yöresel yemek kavramı "kökeni, adı ve ünü belirli bir yöreye ait olan ürünler" olarak ortak bir tanıma sahiptir. Söz konusu bu çalışmalar bölgesel zenginliklerden turizmde yararlanmak için yöresel yemeklerin önemli bir değer olduklarını ve yöresel yemeklere restoranlarda yer vererek turistik deneyimlerin daha zengin, unutulmaz ve eşsiz olacağını vurgulamaktadır. Bu araştırmalar ilkin inceledikleri bölgenin yöresel yemek kültürü ve yemekleri hakkında bilgiler sunmuş; sonrasında yöresel yemeklerin restoranlarda sunumunu menü kartlarını inceleyerek tespit etmişlerdir. Tablo 1'de özetlenen bu çalışmalar 2014 y1lından günümüze kadar geçen süreçte ağırlık kazanmaktadır. Çalışmalardan üçü bildiri, on biri ise makale olarak yayınlanmış; on biri nitel, diğer üçü ise karma yöntemle ele alınmıştır. Araştırmaların Marmara Bölgesi (1), İç Anadolu Bölgesi (3), Ege Bölgesi (-), Akdeniz Bölgesi (1), Karadeniz Bölgesi (4), Doğu Anadolu Bölgesi (2) ve Güneydoğu Anadolu Bölgesi (3) şeklinde dağılım gösterdiği anlaşılmaktadır. Bunlardan 9'u şehir merkezinde gerçekleştirilirken; 5'inin ilçeleri ya da turizm bölgelerini (Ayder, Palandöken gibi) inceledikleri anlaşılmaktadır. Araştırmalar bağımsız restoranlar (9), otel restoranları (2), hem bağımsız restoranlar hem de otel restoranları (3) olmak üzere çeşitli restoran türlerinde gerçekleştirilmiştir. İncelenen restoranların sayısı 5 ile 212 arasında değişim göstermektedir.

$\mathrm{Bu}$ araştırmaların amacı, gastronomik açıdan son derece değerli olduğu ifade edilen yöresel mutfak unsurlarının temsili konusunda bir durum analizi gerçekleştirmektir. Türk halk mutfağının önemli bir parçasını oluşturan yöresel yemeklerin temsil edilme durumunu restoranların menü kartları üzerinden inceleyen bu çalışmalar, genellikle belirli bir şehirle 
sınırlandırılmış; yöresel yemeklerin kullanımını arttırmak adına yapılması gerekenleri tartışmışlardır. Söz konusu araştırmalar bölgesel anlamda çok değerli bilgiler sunmaktadır. $\mathrm{Bu}$ araştırma ise Türk halk mutfağının önemli bir parçası olan yöresel yemeklerin restoranlarda sunumunu ele alan çalışma bulgularını derleyerek daha bütüncül bir bakış açısı sunmayı hedeflemektedir. Bu bütüncül hedef doğrultusunda araştırma dört araştırma sorusu belirlemiştir. Araştırma soruları belirlenirken seçilen çalışmaların tümünde bu sorulara yanıtlar barındırması da dikkate alınmıştır. Bu şekliyle araştırmaya dahil edilen çalışmaların aşağıdaki soruları oldukça yeterli şekilde cevaplandırabileceği düşünülmektedir.

- Yöresel yemeklerin turizmle ilişkisini nasıl tanımlanmaktadır?

- Yöresel yemeklerin restoranlarda sunulma oranı nedir?

- Yöresel yemeklerin restoranlarda sunulmasında hangi faktörler belirleyicidir?

- Yöresel ürünlerin restoranlarda sunulmasına ilişkin ne gibi öneriler sunulmaktadır?

$\mathrm{Bu}$ soruların yanıtlanmasıyla Türk mutfağının yapıtaşı olan yöresel mutfakların hangi bağlamlarda turizmle ilişkilendirildiği anlaşılmış; yöresel yemeklerin hangi şehirlerde başarıyla temsil edildiği görülmüştür. Ayrıca araştırma yöresel yemeklerin sunumlarında öne çıkan faktörleri ve bu bağlamda getirilen önerileri derleyerek daha bütüncül bir bağlam geliştirmiştir.

\section{YÖNTEM}

Araştırma sorularına yanıt aramak için meta sentez yaklaşımı tercih edilmiştir. Meta sentez, nitel araştırma bulgularının daha biçimsel bir çerçevede, anlaşılır şekilde sunulduğu oldukça yeni bir nitel araştırma yaklaşımıdır. Bu yöntem, aynı veya ilgili bir konuyla bağlantılı diğer nitel araştırmalardan elde edilen bulguları veri olarak kullanan bir nitel çalışma türüdür. Meta sentez, belirli bir konudaki nitel alanyazının bütünleşik bir incelemesi ya da seçilen çalışmalardan elde edilen birincil verilerin ikincil veri analizi değildir. Araştırmaya dahil edilen çalışma bulgularının bir başka araştırmada sentezlenerek yeniden yorumlanmasıdır (Zimmer, 2006).

Bir meta-sentez araştırması, araştırmacı tarafından ortaya atılan belirli bir araştırma sorusuyla olan ilgilerine göre seçilen bireysel nitel çalışmalardan oluşur. Yukarıda ayrıntılı olarak sunulan araştırmalar incelendiğinde bu araştırmaların yöresel yemek kavramını ortak bir bağlamda kullandıkları, yöresel yemekler ve turizm ilişkisini inceledikleri, gastronominin turizmdeki etkinliğini anlamak adına yöresel yemeklerin restoran menülerindeki oranını bir temel ölçüt olarak gördükleri söylenebilir. Aynı zamanda araştırmaya dahil edilen çalışmaların tümü yöresel yemeklerin restoranlarda sunulma durumu ve bunun turizmle ilişkisini menü kartları üzerinden yürütmekte, sonrasında katılımcılarla yüz yüze görüşmeler gerçekleştirmektedir. Yöresel bazda oldukça değerli bilgilere sahip olan bu çalışmaların bu araştırma kapsamında bütüncül çıkarımlar sunmaya yarayacak bulgulara sahip oldukları anlaşılmaktadır. Benzer araştırma konuları ve desenlerine sahip olmaları nedeniyle de meta sentez yönteminin uygun bir araştırma yöntemi olduğu sonucuna varılmıştır.

Meta sentezin uygulanması konusunda Walsh ve Downe (2005) tarafindan sunulan adımlar izlenmiştir. İlkin meta sentez yapılacak alan belirlenmiştir. Bu aşamada araştırma Türkiye'nin çeşitli bölgelerinde yöresel yemeklerin restoranlarda sunulmasını ele alan çalışmalarla sınırlandırılmıştır. Sonrasında bu çalışmaların hangilerinin incelemeye alınacağına karar verilmiştir. Bu nedenle yukarıda, Tablo 1'deki araştırmaların tümü çalışmaya dahil edilmiştir. Ancak alanyazın taramasında yöresel ürünler ve restoranları inceleyen farklı araştırmalara da 1036 
rastlanmıştır. Örneğin yöresel yemeklerin restoranlarda sunulmasını nicel araştırma yöntemiyle ele alan Kaya ve Sormaz'ın (2019) çalışması araştırmaya dahil edilmemiştir. Aynı zamanda alanyazında yerel yiyeceklerin (Yarış ve Cömert 2015) ve deniz ürünlerinin (Tüfekçi vd. 2016) restoran menülerinde yer alma durumunu ele alan çalışmaya rastlanmıştır. Ancak bu çalışmalar yöresel yemekleri incelemedikleri için kapsam dişı bırakılmıştır. Araştırmaya dahil edilen çalışmaların bazılarının karma araştırma desenine sahip oldukları göz önünde bulundurulmuş ve sadece nitel bulguları analize alınmıştır. Bu kapsamda seçilen araştırmalara A1'den A14'e kadar kod numaraları verilmiştir (Bkz. Tablo 1). Üçüncü aşama söz konusu araştırmalarda nelerin inceleneceğidir. Araştırma sorularıyla uyumlu olarak yöresel yemekler ve turizm ilişkisi; yöresel yemeklerin restoranlarda sunulma durumu (bu kısımda nicel ifadeden kaçınılmış olup yöresel yemeklerin ne oranda restoranlarda temsil edildiği nitel betimlemelerle açıklanmıştır); yöresel yemeklerin restoranlarda sunulmasında belirleyici olan faktörler ve yöresel ürünlerin restoranlarda temsilini kolaylaştırıcı önerilerin ortaya çıkarılması amaçlanmıştır. Dördüncü aşama çalışmaların değerlendirilmesini içermektedir. $\mathrm{Bu}$ kısımda yukarıda sözü edilen çalışmalar araştırma soruları bağlamında incelenmiştir.

Meta sentez çalışmasının inandırıcılığını arttırmak için Polat ve Ay (2016) tarafından sunulan önerilere uyulmuştur. $\mathrm{Bu}$ aşamada araştırma soruları oldukça açık biçimde ifade edilmiş; araştırmaya dahil edilen araştırmalar ve araştırmadan çıkarılan araştırmalar ayrıntılı olarak açıklanmıştır. Analiz edilen 14 çalışmayla ilgili ayrıntılı bilgiler tablo halinde verilmiştir. Meta sentez yöntemini kullanan araştırmalarda optimum sayı 8-12 olduğundan bu araştırmada ele alınan çalışma sayısının niceliksel olarak yeterli olduğu söylenebilir. Temalar tümdengelim yöntemiyle gerçekleştirilmiş ve temaların oluşumunda nitel araştırma konusunda deneyimle iki farklı araştırmacı görev almıştır. Temaların ve alt kategorilerin isimlendirilmesi analiz gerçekleştiren akademisyenlerin birlikte yürüttüğü tartışmalarla yapılmıştır. Bulguların hangi araştırmalardan sentezlendiği her bulgu sonrasında araştırma kodları parantez içinde sunularak gösterilmiştir. Sentezleme süreci Mart 2020 ile Eylül 2020 tarihleri arasında tamamlanmıştır.

\section{BULGULAR}

Araştırma soruları bağlamında elde edilen bulgular dört ana tema altında gruplandırılmıştır. Bulgulara ilişkin ayrıntılı bilgiler Tablo 2'de görülebilir. Temalar altında açıklanan her bir alt kategori ve bu kategoriler altında yer alan ifadeler, incelenen araştırmalarda bahsedilme sıklığı göz önünde bulundurularak listelenmiştir. Daha açık bir ifadeyle daha fazla değinilen konular önce, daha az değinilen konular da sonra açıklanmıştır.

\section{Yöresel Mutfak Turizm İlişkisi}

Söz konusu ana tema 3 alt kategoride incelenmektedir. Bu bağlamda incelenen çalışmalar yöresel mutfak ve turizmi sürdürülebilirlik, pazarlama aracı olma ve deneyim aracı olma konularıyla ele almaktadır. Çalışmalarda en fazla dile getirilen konulardan biri yöresel yemeklerin restoranlarda sunumunun mutfak kültürü ve kültürel mutfak mirasının sürdürülebilirliğini sağlamasıdır (A1, A2, A3, A6, A8, A12). Buna ek olarak istihdam ve ek gelir imkânları yaratarak kırsal ekonomiye katk1 sunduğu da belirtilmektedir (A1, A2, A6, A13). Kırsal turizmin tamamlayıcısı olma da sürdürülebilirlik konusundaki üçüncü alt kategoridir (A1). 
Yöresel yemeklerin bir pazarlama aracı olarak görülmesi yöresel mutfak ve turizm ilişkisi içinde öne çıkan bir diğer konudur. Buna göre bir bölgenin sahip olduğu yöresel yemekler o bölge için önemli bir çekim unsuru olabilir (A1, A2, A5, A8, A9, A10, A11, A13). Aynı zamanda yöresel yemekler destinasyonu farklılaştırmaya ve rekabet üstünlüğüne (A1, A2, A8) ve destinasyon markalaşmasına da olumlu katkılar sağlamaktadır (A3, A5). Buna ek olarak yöresel mutfaklar alternatif turizm ürünü olan (A10) bir pazarlama aracı olarak görülmektedir (A7).

Turistleri destinasyona çekmenin yanında yöresel yemekler önemli bir deneyim aracı olarak da görülmektedir. Gündelik yaşamlarından uzaklaşan ve farklı bir ortamda farklı deneyimler yaşayan turistler için yöresel yemekler müşteri memnuniyetinin önemli bir parçası olarak dile getirilmektedir (A3, A11). Bölgenin yöresel, geleneksel ve tarihsel yansımalarının deneyimlendiği otantik deneyim, yöresel yemeklerin bir eseri gibi görülmektedir. (A3). Ayrıca yöresel yemeklerin tüketimi bölge kültürünün daha iyi tanınmasına da olanak sağlamaktadır (A1, A11).

\section{Yöresel Yemeklerin Restoranlarda Temsil Edilme Durumu}

İkinci ana temayı oluşturan yöresel yemeklerin restoranlarda sunulma durumu meta sentez yaklaşımın doğası gereği nicel bir tanımlamadan uzak durarak ifade edilmiştir. Restoranlarda sunulan yöresel yemeklerin standart bir şekilde sınıflandırılmamış olmaları, çalışmaların bu bulguları birbirlerinden farklı şekillerde sunmuş olması bunda etkendir. Ancak bunu yaparken incelenen araştırmalarda sunulan betimsel istatistikler dikkate alınmıştır. Söz gelimi Bolu'da \%62.5; Gaziantep'te \%78.9; Adana ve Mersin'de ise \%84.3 gibi yöresel yemeklerin menüdeki tüm yemeklere olan oranı dikkate alınmış ancak bunlar aktarılırken meta sentez yönteminin doğasına uyularak bu durum nitel tanımlamalarla sunulmuştur. Böylece Tablo 2'de de sunulduğu gibi "az miktarda, kısmen ve çoğunlukla yer veren" olmak üzere üç farklı kategori oluşturulmuştur. Bu kategorileri oluştururken bir devlet üniversitesinin Turizm Fakültesi, Gastronomi ve Mutfak Sanatları Bölümünde çalışan bir öğretim elemanından bu konuda bir değerlendirme yapması istenmiş ve uzman görüşüne başvurulmuştur. $\mathrm{Bu}$ doğrultuda söz konusu şehirlerdeki restoranlarda yöresel yemek sunumunun ortak bir paydada tanımlanabileceği konusunda mutabık kalınmıştır. Az miktarda nitelemesi yöresel yemeklerin az düzeyde temsil edildiği ya da hemen hemen hiç temsil edilmediği şehirleri; kısmen temsil edilenler şehre ya da bölgeye ait bazı ikon yiyeceklerin temsilini; çoğunlukla yer verenler ise yöresel yemeklerin restoranlarda kolaylıkla yer bulduğu şehirleri tanımlamaktadır.

İncelenen araştırmalarda Rize (Çamlıhemşin) (A3), Karaman (A7), Eskişehir (A8), Kilis (A9), Adıyaman (A10) mutfağına ait yöresel yemeklerin oldukça az düzeyde restoranlarda temsil edildikleri anlaşılmaktadır. Trabzon (Uzungöl) (A1), Erzurum (Palandöken) (A2), Konya (A4), Sakarya (Tarakl1) (A6), Sinop (A12), Erzincan (A13) ise yöresel yemeklerin kısmen restoranlarda yer bulduğu şehirlerdir. Karalahana çorbası, tereyağında alabalık, kuymak-muhlama, turşu kavurma gibi ürünler Trabzon yöresel mutfağını temsil eden ve restoranlarda yer bulan ürünlerdir. Cağ kebabı, ayran aşı, kesme aşı ve kadayıf dolması gibi yemekler Erzurum yöresel mutfağını temsil etmekte ve restoranlarda yer bulabilmektedir. Arabaşı, bamya çorbası, etli ekmek ve firın kebabı Konya mutfağını restoranlarda temsil eden yöresel yemeklerdir. Keşkek Sakarya (Taraklı) restoranlarında; Sinop mantısı Sinop restoranlarında; kasefe ise Erzincan restoranlarında en fazla sunulan yöresel ürünlerdir. 
Ancak bu şehirlerde incelenen restoranlarda sunulan diğer yemeklerle kıyaslandıklarında bu yöresel yemeklerin restoran menülerinde kısmen yer buldukları anlaşılmaktadır.

Tablo 2. Yöresel Yemeklerin Restoranlarda Sunumu Bağlamında Öne Çıkan Konular

\begin{tabular}{|c|c|c|}
\hline $\begin{array}{l}\text { ANA } \\
\text { TEMALAR }\end{array}$ & $\begin{array}{l}\text { ALT } \\
\text { KATEGORILER }\end{array}$ & KISA AÇIKLAMALAR / ARAŞTIRMA KODLARI \\
\hline \multirow{3}{*}{$\begin{array}{l}\text { Yöresel Mutfak } \\
\text { ve Turizm } \\
\text { İlişkisi }\end{array}$} & Sürdürülebilirlik & $\begin{array}{l}\text { Mutfak kültürünün ve kültürel mutfak mirasının sürdürülebilirliğini } \\
\text { sağlama (A1, A2, A3, A6, A8, A12) } \\
\text { İstihdam ve ek gelir sağlayarak kırsal ekonomiye katkı sunma (A1, A2, } \\
\text { A6, A13) } \\
\text { Kırsal turizmin tamamlayıcısı olma (A1) }\end{array}$ \\
\hline & Pazarlama Aracı & $\begin{array}{l}\text { Destinasyona turist çekmeye yardımcı olması (A1, A2, A5, A8, A9, } \\
\text { A10, A11, A13) } \\
\text { Destinasyonu farklılaştırması ve rekabet üstünlüğü sağlama (A1, A2, } \\
\text { A8) } \\
\text { Destinasyon markalaşmasına yardımcı olur (A3, A5) } \\
\text { Otantik Yöresel yemeklerin turizm pazarlaması aracı olarak kullanımı } \\
\text { (A7) } \\
\text { Alternatif turizm ürünü olma (A10) }\end{array}$ \\
\hline & Deneyim Aracı & $\begin{array}{l}\text { Farklı bir deneyim sunması yoluyla müşteri memnuniyetini arttırması } \\
\text { (A3, A11) } \\
\text { Bölge kültürünü daha iyi tanıma firsatı sunması (A1, A11) } \\
\text { Otantik deneyim sunması (A3) }\end{array}$ \\
\hline \multirow{3}{*}{$\begin{array}{l}\text { Yöresel } \\
\text { Yemeklerin } \\
\text { Restoranlarda } \\
\text { Temsil Edilme } \\
\text { Durumu }\end{array}$} & $\begin{array}{l}\text { Az miktarda yer } \\
\text { veren şehirler }\end{array}$ & $\begin{array}{l}\text { Rize (Çamlıhemşin) (A3) } \\
\text { Karaman (A7) } \\
\text { Eskişehir (A8) } \\
\text { Kilis (A9) } \\
\text { Adıyaman (A10) }\end{array}$ \\
\hline & $\begin{array}{l}\text { Kismen yer veren } \\
\text { şehirler }\end{array}$ & $\begin{array}{l}\text { Trabzon (Uzungöl) (A1) } \\
\text { Erzurum (Palandöken) (A2) } \\
\text { Konya (A4) } \\
\text { Sakarya (Tarakl1) (A6) } \\
\text { Sinop (A12) } \\
\text { Erzincan (A13) }\end{array}$ \\
\hline & $\begin{array}{l}\text { Çoğunlukla yer } \\
\text { veren şehirler }\end{array}$ & $\begin{array}{l}\text { Gaziantep (A5) } \\
\text { Bolu (Mengen) (A11) } \\
\text { Adana ve Mersin (A14) }\end{array}$ \\
\hline \multirow{2}{*}{$\begin{array}{l}\text { Yöresel } \\
\text { Yemeklerin } \\
\text { Restoranlarda } \\
\text { Sunumunu } \\
\text { Etkileyen } \\
\text { Faktörler }\end{array}$} & Üretim Boyutu & $\begin{array}{l}\text { Bazı yöresel yemeklerin önceden hazırlanmasının gerekmesi, hazırlanan } \\
\text { ve beklenen yemeklerin de lezzet kaybı yaşaması (A3, A9, A11) } \\
\text { Bazı yöresel yemeklerin yapımının zahmetli olması (A4, A9, A10) } \\
\text { Yöresel yemekleri yapan şeflerin sayısının az olması (A4, A7) } \\
\text { Yöresel yemeklerin karının düşük olması (A4, A9) } \\
\text { Yöresel yemeklerin istenildiği biçimde profesyonelce hazırlanamaması } \\
\text { (A3) }\end{array}$ \\
\hline & Tüketim Boyutu & $\begin{array}{l}\text { Talep oluşmaması yöresel yemeklerin menülerde yer almasında büyük } \\
\text { engel. (A3, A9, A11, A12) } \\
\text { Yöresel halkın yöresel yemekleri restoranlarda fazla talep etmemeleri } \\
\text { (A4; A9) } \\
\text { Yöresel yemeklerin turistler tarafından yeterince bilinmemesi (A7) }\end{array}$ \\
\hline \multirow{2}{*}{$\begin{array}{l}\text { Yöresel } \\
\text { Yemeklerin } \\
\text { Restoranlarda } \\
\text { Sunumu } \\
\text { Hususunda Öne } \\
\text { Çıkan Öneriler }\end{array}$} & $\begin{array}{l}\text { Yöresel yemeklerin } \\
\text { yeniden } \\
\text { keşfedilmesi }\end{array}$ & $\begin{array}{l}\text { Unutulmaya yüz tutan yemeklerin reçetelendirilmesi (A4, A5, A8) } \\
\text { Yöresel yemekler konusunda bilimsel toplantılar düzenlenmeli (A6, A7) } \\
\text { Yöresel yemeklerin tescillenmesi (A3) }\end{array}$ \\
\hline & $\begin{array}{l}\text { Yöresel yemeklerin } \\
\text { yaygınlaştırılması }\end{array}$ & $\begin{array}{l}\text { Etkinliklerde yöresel mutfağa yer verme (A4, A7, A11, A13) } \\
\text { Tanıtım faaliyetlerinin gerçekleştirilmesi (A6, A5, A8,A9) } \\
\text { Yöresel mutfakla ilgili kitap vb. yayınların yapılması (A3, A4, A7) } \\
\text { Sivil toplum kuruluşları ve kamu kuruluşlarını yöresel mutfak } \\
\text { konusunda bilgilendirme ve bu kuruluşlarla işbirliği kurma (A6, A8) }\end{array}$ \\
\hline
\end{tabular}


Halk eğitim merkezlerinde yöresel yemek eğitimleri verilmeli (A6, A11)

Menü kartlarında yöresel yemekleri tanıtan ibarelere yer verilmesi (A1,

A7)

Yöresel mutfak konusunda restoran işletmecilerinin bilgilendirilmesi

(A3)

Yöresel yemeklerin tanıtıldığ bir mutfak müzesi açılmalı (A3)

Yöresel yemek kursları (turistler için) (A3)

Yöresel mutfaklarını etkin kullanan ülkeler örnek alınmalı (A6)

Yöresel yemeklerin sunulduğu restoranlara teşvik edici ödüllendirmeler yapilması (A9)

Yemeklerin profesyonel mutfaklarda sunulmaları için yeni teknolojik ekipmanların kullanılması (vakum makinası gibi) (A9)

Bazı ikon yemeklerin restoranlarda temsiline ek olarak yöresel mutfağın yoğun olarak görüldüğü şehirler de bulunmaktadır. Gaziantep (A5), Bolu (Mengen) (A11), Adana ve Mersin (A14) yöresel mutfağın restoranlarda en fazla temsil edildiği şehirlerdir. İncelenen araştırma bulgularına göre, bu şehirlerde yöresel yemekler restoranlarda oldukça yaygın olarak sunulmaktadırlar.

\section{Yöresel Yemeklerin Restoranlarda Sunumunu Etkileyen Faktörler}

Yukarıda görüldüğü gibi restoranların büyük çoğunluğunda yöresel yemekler az ya da kısmen servis edilmektedir. Buna göre yöresel yemeklerin sunumunu etkileyen ve üçüncü ana temayı oluşturan faktörlerin yöresel yemeklerin sunumunda bir engel teşkil ettiği ifade edilebilir. Yöresel yemeklerin restoranlardaki temsili, üretim ya da tüketimden kaynaklanan nedenlerden etkilenmektedir.

Bazı yöresel yemeklerin önceden hazırlanmasının gerekmesi, hazırlanan ve beklenen yemeklerin de lezzet kaybı yaşaması (A3, A9, A11); bazı yöresel yemeklerin yapımının zahmetli olması (A4, A9, A10); yöresel yemekleri yapan şeflerin sayısının az olması (A4, A7) ve yemeklerin bundan dolayı istenildiği biçimde profesyonelce hazırlanamaması (A3) ile yöresel yemeklerin karının düşük olması (A4, A9) üretimle ilgili temel engellerdir.

Tüketimle ilgili nedenlerse yerel halk ve turistler bağlamında iki farklı boyutta ele alınabilir. Ancak her iki boyutta da ortak bir neden bulunmaktadır. Yöresel yemeklere hem yerel halktan (A4, A9) hem de turistlerden yeterli talebin olmaması (A3, A9, A11, A12). Yöresel yemeklerin turistler tarafindan bilinmemesi de bunda etkendir (A7).

\section{Yöresel Yemeklerin Restoranlarda Sunumu Hususunda Öne Çıkan Öneriler}

Son ana tema ise yöresel yemeklerin restoranlarda sunumu hususunda öne çıkan önerileri gruplandırmıştır. $\mathrm{Bu}$ önerilerde yöresel yemeklerin yeniden keşfedilmesi ve yöresel yemeklerin yaygınlaştırılması şeklinde dikkat çeken iki temel konu bulunmaktadır.

Unutulmaya yüz tutan yemeklerin reçetelendirilmesi (A4, A5, A8), yöresel yemekler konusunda bilimsel toplantılar düzenlenmesi (A6, A7) ve yöresel yemeklerin tescillenmesi (A3) kültürel açıdan son derece önemli olan yöresel yemeklerin yeniden keşfedilmesi ve yaşatılması için getirilen önerilerdir.

Yöresel yemeklerin yaygınlaştırılması konusunda yapılması gerekenlerse şöyle özetlenebilir. Yöresel mutfaklarla ilgili tanıtım faaliyetlerinin yapılması (A6, A5, A8,A9); yöresel yemeklerin sunulduğu etkinliklerin düzenlenmesi ve mutfak müzesi gibi tesislerin açılması 
(A3, A4, A7, A11, A13), yöresel mutfakları tanıtan yayınların yapılması (A3, A4, A7) ve restoran menü kartlarında yöresel mutfaklarla ilgili tanıtıcı bilgiler sunulması (A1, A7).

Bir diğer yaygınlaştırma çalışması da eğitim üzerinedir. Sivil toplum kuruluşları ve kamu kuruluşlarını yöresel mutfak konusunda bilgilendirme ve bu kuruluşlarla iş birliği kurma (A6, A8); çeşitli merkezlerde yerel halka, işletmecilere ve turistlere yöresel mutfak eğitimleri verme (A3, A6, A11) eğitim üzerine geliştirilen temel önerilerdir.

$\mathrm{Bu}$ konulara ek olarak yöresel mutfağı etkin kullanan ülkeler örnek alınması (A6); yöresel yemeklerin sunulduğu restoranlara teşvik edici ödüllendirmeler yapılması (A9) ve yöresel yemeklerin profesyonel mutfaklarda sunulmaları için yeni teknolojik ekipmanların kullanılması (vakum makinası gibi) (A9) bu konuda getirilen diğer önerilerdir.

\section{TARTIŞMA VE SONUÇ}

Araştırma kapsamında Türkiye'de yöresel yemeklerin sunumunu restoranlarda ele alan çalışmalar incelenmiştir. İlk temada yöresel yemekler sürdürülebilir turizme katkı sağlama, etkili bir pazarlama aracı olma ve turizm deneyimini zenginleştirme konularında turizmle ilişkilendirilmektedir. Bu ilişki öncül araştırma bulgularıyla da desteklenir. Yöresel yemeklerin sürdürülebilir mutfak mirasına katkı sağladığı (Beer vd. 2002); destinasyonu farklılaştırarak etkin bir pazarlama aracı işlevi gördüğü (Fox 2007) ve turist deneyimini zenginleştirdiği anlaşılmaktadır (Everett 2012, Silkes vd. 2013). Ancak tüm bu olumlu etkilerine rağmen yöresel yemeklerin her destinasyonda etkin biçimde kullanılabildiğini söylemek doğru olmaz. Özdemir ve Seyitoğlu (2018) gastronomi ve turizm ilişkisini ele aldıkları kavramsal çalışmalarında bazı destinasyonlar için gastronominin ana bileşen olduğunu, bazıları için ise destekleyici bir rol oynadığını ifade etmektedir. Bundan yola çıkarak yöresel yemeklere restoranlarda sıklıkla yer veren Gaziantep, Adana, Mersin ve Bolu gibi şehirlerin gastronomiyi ana bileşen olarak gördükleri söylenebilir. Öyle ki Gaziantep'in “Türkiye'nin Gastronomi Başkenti” olarak görülen, Unesco Yaratıcı Şehirler Ağı üyesi olması bu durumu kanıtlamaktadır (Solunoğlu ve Nazik 2018). Buna ek olarak Adana ve Mersin de ülkemizde gastronomik ağırlığı olan şehirlerdir. Bolu (Mengen) ise "Aşçıllı̆̆ın Başkenti” olarak tanımlanmaktadır (https://mengen.bel.tr/index.php). Dolayısıyla bahsedilen bu şehirlerdeki restoranlarda yöresel yemeklerin sıklıkla kullanımı gastronominin ana bileşen olmasıyla alakalı olabilir. Bunun dışında kalan ve yöresel yemeklerin kısmen ya da az kullanıldığı şehirlerin yöresel mutfağı turizmde ikinci planda tuttukları söylenebilir.

İncelenen çoğu şehirde yöresel yemeklerin kısmen ya da az sunulması üretim ve tüketim temelli, çoğunlukla da engelleyici faktörlerin olduğunu göstermektedir. Yöresel yemeklerin hazırlanmasının zahmet gerektirmesi, şeflerin yöresel yemekler konusunda yetersiz olmaları gibi nedenler dikkat çekmektedir. Bu nitelikler Aslan vd. (2015) ve Nebioğlu'nun (2020) çalışma bulgularıyla da benzerlik göstermektedir. Yapımı zahmet isteyen ve şefler tarafından bilinmeyen bu yemekler restoranlarda sunulma konusunda sıkıntılar yaşamaktadır.

Konuya tüketim boyutundan bakıldığında da bir destinasyonun gastronomi turizmi stratejisinde görüldüğü gibi benzer bir ayrılma görülür. Her destinasyon gastronomi turizmini desteklemediği gibi her turist için de yöresel yemekler aynı anlamları taşımaz. Bazıları için yemek seyahat etme nedeniyken bazı turistler için ise basit, fizyolojik bir ihtiyaçtır. Bu bağlamda Aktaş-Alan ve Suna'nın (2019) yaptığı çalışma son derece dikkat çekicidir. Gaziantep'te restoran yöneticileriyle yapılan çalışma menü planlaması konusuna odaklanmaktadır. Şeflerin görüşlerine göre menüdeki yemekleri talep belirlemektedir. Talep 
olduğu oranda yöresel yemekler restoranlarda kendine yer bulmaktadır. Bunun benzeri bir bulguya Ak'ın (2019) çalışmasında rastlanır. Alanya'daki turistik restoranları inceleyen araştırma bulguları restoran menülerinde çoğunlukla uluslararası yemeklere yer verildiği ifade etmektedir. $\mathrm{Bu}$ araştırmaya göre de turistler bilindik yemekleri tercih ettiklerinden menüdeki yemeklerin çoğunun yöresel değil, bilindik ulusal (döner, kebap, pide vb.) ya da uluslararası (makarna, pizza vb.) yemekler olduğu anlaşılmaktadır. Bu durumda yöresel yemekler üretim faktörlerinden etkilendiği kadar tüketim faktörlerinden de etkilenmektedir. Restoranlar için bu yemeklerin ticari anlamda restoran amaçlarını gerçekleştirecek özelliklerde olması beklenmektedir. Daha ayrıntılı olarak bu yemekler hem profesyonel mutfaklarda üretilebilecek hale getirilmeli hem de insanların bu yemekleri tüketmeye karşı bir talepleri olmalıdır. Ekonomideki arz talep dengesinin yöresel yemekler ve restoranlar bağlamında da geçerli olduğu görülmektedir.

Araştırmalardaki öneriler yöresel yemeklerin yaşatılması ve yaygınlaştırılması şeklinde ikiye ayrılmaktadır. Söz konusu öneriler oldukça önemli olsa da yöresel mutfağın turistik bir destinasyonda kullanılmasında belirli bir strateji izlenmesi gerekmektedir. Araştırmalarda verilen öneriler bu stratejileri işaret etmekten uzaktır. Bu aşamada Hjalager (2002) tarafindan sunulan yöresel gastronomik ürün gelişim stratejisi örnek alınabilir. Dört aşamadan oluşan bu stratejide ilk aşamada yöresel yemekler gün yüzüne çıkarılır, ikinci aşamada bu yemeklere ait standardizasyon işlemleri (coğrafi işaret, marka oluşturma vb.) geliştirilir; üçüncü aşamada bu ürünler farklı ürünlere entegre edilerek yaygınlaşması sağlanır; dördüncü ve son aşamada ise yeni yöresel ürün geliştirme çalışmaları yer alır. Dolayısıyla yöresel yemeklerin gün ışı̆̆ına çıkarılması yeterli değildir, bunların taklit edilmelerini önlemek ve farklı paydaşlarla başarılı ticari ortaklıklar gerçekleştirerek yöresel yemeklerin yaygınlaşması sağlanmalıdır. Tüm bu bulgulardan yola çıkarak araştırmanın getirdiği temel öneri şöyledir. Yöresel yemeklerin restoranlarda sunumunun incelenmesi sadece yöresel mutfağın temsili hakkında bir durum analizi sunar. $\mathrm{Bu}$ noktada yapılması gereken pek çok değişkeni göz önünde bulundurarak belirli stratejilerle yöresel mutfağın temsilini arttırmak olmalıdır.

$\mathrm{Bu}$ noktada araştırmanın sınırlılıklarından da söz edilebilir. Farklı ülkelerde de benzer desende yapılan araştırmalara rastlansa da yapılan alanyazın taramasında özellikle "Yöresel yemek ve turizm" ilişkisini restoranlarda ele alan çalışmaların ülkemizde yoğunlaştığ1 anlaşılmıştır. $\mathrm{Bu}$ nedenle araştırma yerli yazındaki araştırmalara odaklanmıştır. $\mathrm{Bu}$ bir sınırlılık olarak kabul edilebilir. Araştırma bulgularının yöresel yemeklerin restoranlarda sunumunu ele alan on dört çalışmadan elde edilmesi; bu nedenle sadece inceledikleri şehirler ve bu şehirlerdeki restoranlara ait bilgiler sunması da başka bir sınırlılık olarak gösterilebilir. Ancak sadece yerli yazındaki çalışmalar ve bu çalışmaların bulgularının dikkate alınmasının ulusal çapta daha anlamlı çıkarımlar sunulmasına olanak sağladığı da unutulmamalıdır.

$\mathrm{Bu}$ bulgulardan yola çıkarak turizm ve yöresel yiyecekler arasındaki ilişkilerin destinasyonlar bağlamında daha ayrıntılı biçimde incelenmesine gerek vardır. Yöresel yemek ve turizm ilişkisi sürdürülebilirlik, pazarlama aracı ve bir deneyim aracı olmanın yanında farklı özelliklere sahip olabilir mi? Bu konunun derinlemesine incelenmesi gerekebilir. Buna ek olarak yöresel yemeklerin üretim ve tüketimlerini etkileyen faktörlerin daha ayrıntılı şekilde irdelenmesi de gerekmektedir. Bir diğer öneri ise incelenen restoran sayısı üzerine getirilebilir. Araştırmaya dahil edilen çalışmaların dokuzunda 20 ve daha az restoran incelendiği görülmektedir. Gelecekteki araştırmaların kapsamlarını geliştirerek daha fazla restorana ulaşmaları önerilir. 
Hem akademisyenlerin hem de uygulamacıların yukarıda ifade edilen faktörleri göz önünde bulundurarak yöresel yemeklerin yaygınlaştırılması hususunda ortak stratejiler geliştirmeleri önerilmektedir. Bunu yapabilmek için söz konusu yemeklerin reçeteleri standart bir hale getirilmeli, bu yemeklerin bulunduğu şehirle olan bağlantısını güçlendirmek için coğrafi işaret belgesi alınmalıdır. Yemekler turizmde festivaller, yemekle ilgili müzeler, restoranlar gibi alanlarla bütünleştirilmelidir. Bunu yaparken de tüm paydaşların böyle bir girişime dahil edilebilmesi sağlanmalıdır.

Son bir öneri de yönteme ilişkin yapılabilir. Meta-sentezden elde edilen kanıtın olumsal doğasına ve bazı yönleri hakkında hâlihazırda fikir birliği olmamasına rağmen, meta-sentez nitel araştırmacılar için önemli bir tekniktir (Walsh ve Downe 2005). Alanyazına bütüncül bir bağlam kazandırdığından bu yöntemin turizm ve gastronomi çalışmalarında daha fazla kullanılması önerilmektedir.

\section{KAYNAKÇA}

AK S. (2019). Turist Odaklı Restoranlar Üzerine Bir Olgubilim Çalışması. Akdeniz Üniversitesi, Sosyal Bilimler Enstitüsü, Gastronomi ve Mutfak Sanatları Ana Bilim Dalı Yayımlanmamış Yüksek Lisans Tezi.

AKDEMİR, N. \& SELÇUK, G. N. (2017). Mutfak Kültürünün Sürdürülebilirliği Bakımından Yöresel Yiyeceklerin Menülerde Yer Alma Düzeyi: Taraklı Ölçeğinde Bir Araştırma. 1st International Sustainable Tourism Congress / November 23-25, 2017 / KastamonuTurkey.

AKTAŞ ALAN A., \& SUNA, B. (2019). “Gastronomi Şehri Gaziantep’te Menü Planlama Uygulamalarına Güncel Bakış”. Journal of Tourism and Gastronomy Studies, 7 (2): 1328-1343.

ASLAN, Z., GÜNEREN, E., \& ÇOBAN, G. (2014). "Destinasyon Markalaşma Sürecinde Yöresel Mutfağın Rolü: Nevşehir Örneği”. Journal of Tourism and Gastronomy Studies, 2(4): 3-13.

ASSUNÇÃO BOTELHO, R. B., ARAÚJO, W. M. C., \& ZANDONADI, R. P. (2020). "Main Regional Foods Offered in Northeast Brazilian Restaurants and Motives for Their Offer". Journal of Culinary Science \& Technology: 1-18.

AVIELI, N. (2013). "What is 'local food? Dynamic culinary heritage in the World Heritage Site of Hoi An", Vietnam. Journal of Heritage Tourism, 8(2-3): 120-132.

AYLAN, S., İŞ, M., YEŞİLÇİMEN, P. (2017). "Turizm Açısından Yöresel Yemeklerin Pazarlama Aracı Olarak Kullanılması: Karaman İli Örneği”. Kesit Akademi Dergisi, 3(10): 446-462.

BATRA, A. (2008). "Foreign Tourists' Motivation and Information Source(s) Influencing Their Preference for Eating Out at Ethnic Restaurants in Bangkok", International Journal of Hospitality \& Tourism Administration, 9(1): 1-17.

BLAKEY, C. (2012). “Consuming Place”, Hawai'i Community College HOHONU, 10: 5154. 
BEER, S., EDWARDS, J., FERNANDES, C., \& SAMPAIO, F. (2002). Regional Food Cultures: Integral to the Rural Tourism Product. der. Hjalager A. M., Richards G., 207-223, Tourism and Gastronomy, Londra ve New York, 2002.

BEKAR, A. \& KILIÇ, B. (2014). “Turistlerin Gelir Düzeylerine Göre Destinasyondaki Gastronomi Turizmi Etkinliklerine Katılımları", Uluslararası Sosyal ve Ekonomik Bilimler Dergisi, 4 (1): 19-26.

BİRDİR, K. \& AKGÖL, Y. (2015). “Gastronomi Turizmi ve Türkiye’yi Ziyaret Eden Yabancı Turistlerin Gastronomi Deneyimlerinin Değerlendirilmesi”, İşletme ve İktisat Çalışmaları Dergisi, 3(2): 57-68.

BÜYÜKŞALVARCI, A., ŞAPCILAR, M. C., \& YILMAZ, G. (2016). "Yöresel Yemeklerin Turizm İşletmelerinde Kullanılma Durumu: Konya Örneğì". Journal of Tourism and Gastronomy Studies, 165-181.

CURTIS, K. R. \& COWEE, M. W. (2009). "Direct Marketing Local Food to Chefs: Chef Preferences and Preceived Obstacles", Journal of Food Distribution Research, 40: 2636.

ÇOKIŞLER, N. \& TÜRKER, A. (2015). "Mutfak Kültürünün Turizm Ürünü Olarak Kullanım Etkinliğinin İncelenmesi: Ayder Turizm Merkezi Örneği”. Gümüşhane Üniversitesi Sosyal Bilimler Enstitüsü Elektronik Dergisi, 6(14).

DOUGHERTY M. L. \& GREEN G. P. (2011). "Local Food Tourism Networks and Word of Mouth", Journal of Extension, 49(2).

DU RAND G. E. HEATH E. \& ALBERTS N. (2003). "The Role of Local and Regional Food in Destination Marketing: a South African Situation Analysis", Journal of Travel\&Tourism Marketing, 14(3): 97-112.

DÜNDAR ARIKAN, A. (2017). "Eskişehir'deki Yiyecek İçecek İşletmelerinin Menülerinde Eskişehir Mutfağının Yeri”. Journal of Human Sciences, 14(2): 2061-2077.

ERDEM, Ö., MIZRAK, M., \& KEMER, A. K. (2018). "Yöresel Yemeklerin Bölge Restoranlarında Kullanılma Durumu: Mengen Örneği”. Uluslararası Türk Dünyas1 Turizm Araştırmaları Dergisi, 3(1): 44-61.

EVERETT S., (2012). "Production Places and Consumption Spaces? The Place-making Agency of Food Tourism in Ireland and Scotland", Tourism Geographies, 14(4): 535554.

FOX, R. (2007). "Reinventing the Gastronomic Identity of Croatian Tourist Destinations", Hospitality Management, 26: 546-559.

GİRITLIOĞLU, İ., KARAKAN, H. İ., AYVERDİ, B. \& TOPRAK, E. (2016). Gastronomi Alanında Unesco Şehirler Ağında Olan Marka Şehir Gaziantep'in Yiyecek İçecek İşletmelerindeki Menülerindeki Yöresel Yemek Oranının Tespit Edilmesine Yönelik Bir Çalışma. 3rd International Congress on Social Sciences, China to Adriatic, October 27-30, 2016, 134-142, Antalya / Turkey. 
GÜRSOY, D., (2013). Tiridine Tiridine Suyuna da Bandım, Tarihin Süzgecinde Yöresel Mutfağımız. Oğlak Yayıncılık, İstanbul.

HALL, M., \& MITCHELL, R., (2002). Tourism as a Force for Gastronomic Globalization and Localization, der. Hjalager A. M., Richards G., 71-87, Tourism and Gastronomy, Londra ve New York.

HARRINGTON, R. J., (2005). "Defining Gastronomic Identity: The Impact of Environment and Culture on Prevailing Components, Texture and Flavours in Wine and Food", Journal of Culinary Science and Technology, 4(2/3): 129-152.

HAVEN-TANG, C., \& JONES, E., (2005). "Using Local Food and Drink to Differentiate Tourism Destinations Through a Sense of Place: A Story from Wales-Dining at Monmuthshire's Great Table", Journal of Culinary Science \& Technology, 4(4): 6986.

HJALAGER, A. M. (2002). A Typology of Gastronomy Tourism. Hjalager A. M., Richards G., 21-35, Tourism and Gastronomy, Londra ve New York.

HU, W., QING, P., BATTE, M., WOODS, T., \& ERNST, S. (2013). "What is local and for what foods does it matter?”. Agricultural Economics, 59(10): 454-466.

KABASAKAL L., YALABIK N., ÇAKIR A., ÇAKIR G., ERGÜVEN A. T., ERGÜVEN M. H., TEKELIOĞLU Y., \& ERKE E. (2015). "Bilinçli Mutfak", Beta Yayınları: İstanbul.

KARGİGLIOĞLU, Ş., \& AYYILDIZ, S. (2018). "Mutfak Kültürünün Sürdürülebilirliği Bakımından Yöresel Yiyeceklerin Menülerde Yer Alma Düzeyi: Sinop Ölçeğinde Bir Araştırma”. Akademik Sosyal Araştırmalar Dergisi, 6(86): 346-355.

KAYA, Ş., \& SORMAZ, Ü. (2019). "Yiyecek İçecek İşletmelerinde Yöresel Mutfak Uygulamaları: Gaziantep Örneği”. Gastroia: Journal of Gastronomy and Travel Research, 3(2): 304-323.

KIZILIRMAK, İ., ALBAYRAK, A., \& KÜÇÜKALİ, S. (2014). "Yöresel Mutfağın Kırsal Turizm İşletmelerinde Uygulanması: Uzungöl Örneği”. International Journal of Social and Economic Sciences, 4(1): 75-83.

KIVELA J. \& CROTTS J. C. (2005). “Gastronomy Tourism”, Journal of Culinary Science \& Technology, 4(2-3): 39-55.

KORMANN DA SILVA, M., GOULART ROCHA, F. \& MORTIMER AMARAL, F. (2015). "Gastronomic Use of Fish in Restaurants of the South of Brazil", Journal of Culinary Science \& Technology, 13: 159-174.

KYRIAKAKI, A., ZAGKOTSI, S. \& TRIHAS, N. (2013). Creating Authentic Gastronomic Experiences For Tourists Through Local Agricultural Products: The 'Greek Breakfast' Project. Conference: 5th International Scientific Conference "Tourism Trends and Advances in the 21st Century", At Rhodes, Greece: 2013.

LILLIWHITE J. M. \& SIMONSEN, J. E. (2014). "Consumer Preferences for Locally Produced Food Ingredient Sourcing in Restaurants", Journal of Food Product Marketing, 20: 308-324. 
MASSEY, D. (2005). For space. London: Sage Publications.

Mengen Belediyesi. https://mengen.bel.tr/index.php

MİL, B. \& DENK E. (2015). Erzurum Mutfağı Yöresel Ürünlerin Otel Restoran Menülerinde Kullanım Düzeyi: Palandöken Örneği. International Journal of Social and Economic Sciences, 5(2): 01-07.

NEBİOĞLU, O. (2018). Turistlerin Yemek Tüketim Davranışları Üzerine Kavramsal Bir Değerlendirme. Turizm Akademik Dergisi, 5(1): 124-136.

NEBİOĞLU, O. (2020). Factors Affecting the Production and Presentation of Local Dishes in Restaurants Operating in Touristic Destinations. Journal of Culinary Science and Technology, https://doi.org/10.1080/15428052.2020.1787286.

NUMMEDAL, M., \& HALL, C. M. (2008). Local food in tourism: An investigation of the New Zealand South Island's Bed and Breakfast sector's use and perception of local food. Tourism Review International, 9(4): 365-378. doi: $10.3727 / 154427206776330571$

ÖZDEMİR B. YILMAZ G. \& ÇALIŞKAN O. AYDIN A. (2015). Şeflerin Yerel Yiyeceğe İlişkin Algılamaları ile Yerel Yiyecek Satın Alma Niyetleri Arasındaki İlişki, 16. Ulusal Turizm Kongresi: 418-437.

ÖZDEMIR, B. \& SEYITOĞLU, F. (2018). Gastronomi ve Turizm Bütünleşmesine Stratejik Yaklaşım: Kuramsal Bir Model Önerisi, 19. Ulusal Turizm Kongresi, 17-21 Ekim 2018, Afyonkarahisar - Türkiye, 404-413.

ÖZEL, G., YILDIZ, F., \& AKBABA, M. (2017). "Yöresel Yemeklerin Restoran Menülerinde Yer Alma Düzeyinin Belirlenmesi: Kilis Mutfağı Örneği”. Kesit Akademi Dergisi, 3(11): 351-364.

POLAT, S. \& AY, O. (2016). "Meta-Sentez: Kavramsal Bir Çözümleme”. Eğitimde Nitel Araştırmalar Dergisi- Journal of Qualitative Research in Education, 4(1): 52-64. [Online]: http://www.enadonline.com

REYNOLDS, P. C. (1993). "Food and Tourism: Towards and Understanding of Sustainable Culture", Journal of Sustainable Tourism, 1(1): 48-54.

SHARMA, A., MOON J. \& STROHBEHN, C. (2014). "Restaurant's Decision to Purchase Local Foods: Influence of Value Chain Activities", International Journal of Hospitality Management, 39: 130-143.

SILKES, C. A., CAI, L. A., \& LEHTO, X. Y. (2013). "Marketing to the Culinary Tourist", Journal of Travel \& Tourism Marketing, 30: 335-349.

SIMS, R. (2009). "Food, Place and Authenticity: Local Food and the Sustainable Tourism Experience", Journal of Sustainable Tourism, 17(3): 321-336.

SMITH, S. L. J., \& XIAO, H., (2008). "Culinary Tourism Supply Chains: A Preliminary Examination", Journal of Travel Research, 46: 289-299.

SOLUNOĞLU, A., \& NAZİK, M. H. (2018). "Sokak Lezzetlerine İlişkin Tüketici Tercihleri: Gaziantep Örneği”. Journal of Tourism and Gastronomy Studies, 6(3): 40-59. 
SPARKS, B. BOWEN J. \& KLAG, S. (2003). "Restaurants and the Tourist Market", International Journal of Contemporary Hospitality Management, 15(1): 6-13.

SIMS, R. (2009). "Food, place and authenticity: Local food and the sustainable tourism experience". Journal of Sustainable Tourism, 17(3): 321-336. doi:10.1080/ 09669580802359293

ŞEN, N., \& SİLAHŞÖR, Y. (2018). “Gastronomi Turizmi Kapsamında Erzincan İli Yiyecek İçecek İşletmelerinde Sunulan Yöresel Yemekler Üzerine Bir Araştırma”. Güncel Turizm Araştırmaları Dergisi, 2(Ek1): 414-429.

ŞAVKAY, T. (2000). Osmanlı Mutfağı. Şekerbank: Ankara.

TÜFEKÇİ, Ö. K., TÜFEKÇİ, N. \& KALKAN, G. (2016). Eğirdir Mutfağının Marka Kimlik Unsurlarının Değerlendirilmesi: Menülere İlişkin Bir İçerik Analizi. IMUCO - April 21-22, 2016 Antalya, TURKEY, 218-225.

WALSH, D., \& DOWNE, S. (2005). "Meta-Synthesis Method For Qualitative Research: A Literature Review". Journal of Advanced Nursing, 50(2): 204-211.

WANG, L. W., TRAN, T. T., \& NGUYEN, N. T. (2014). “Analyzing factors to improve service quality of local specialties restaurants: A comparison with fast food restaurants in southern Vietnam". Asian Economic and Financial Review, 4(11): 1592.

YAHYAPOUR, S., SHAMIZANJANI, M., \& MOSAKHANI, M. (2015). “A conceptual breakdown structure for knowledge management benefits using meta-synthesis method". Journal of Knowledge Management, 19(6): 1295-1309.

YARIŞ, A., \& CÖMERT, M. (2015). "Mardin İlindeki Restoranların Yerel Ürün Kullanımındaki Avantaj ve Dezavantajları ile İlgili Algıları". Uluslararası Sosyal Araştırmalar Dergisi, 8(37): 991-998.

YEŞİLYURT, H., YEŞILYYURT C., GÜLER, O., \& ÖZER, S. (2017). Otel İşletmelerinin Menülerinde Yöresel Yemek Kültürünü Yaşatmak: Adıyaman Örneği. IWACT 2017 International West Asia Congress Of Tourism Research 28 Sept - 01 Oct 2017 VanTurkey, 173-183.

YILDIRIM, O., KARACA, O. B., \& ÇAKICI, A. C. (2018). "Yöresel Yemeklere Konaklama ve Yiyecek İçecek İşletmelerinin Menülerinde Yer Verilme Durumu: Adana ve Mersin Bölgesinde Bir Araştırma". Journal of Tourism and Gastronomy Studies, 6(4): 376398.

YÜKSEL A., \& YÜKSEL F., (2002). "Measurement of Tourist Satisfaction with Restaurant Services: A Segment Based Approach”, Journal of Vacation Marketing, 9: 52-68.

ZIMMER, L. (2006). "Qualitative Meta-Synthesis: A Question Of Dialoguing With Texts". Journal of Advanced Nursing, 53(3): 311-318. 